\title{
(-)-Epigallocatechin 3-gallate inhibits invasion by inducing the expression of Raf kinase inhibitor protein in AsPC-1 human pancreatic adenocarcinoma cells through the modulation of histone deacetylase activity
}

\author{
SUNG OK KIM and MI RYEO KIM
}

\begin{abstract}
Department of Herbal Pharmacology of Oriental Medicine, College of Oriental Medicine and R\&D Team for the New Drug of Oriental Medicine (BK21), Daegu Hanny University, Daegu 706-828, Republic of Korea
\end{abstract}

Received August 1, 2012; Accepted October 2, 2012

DOI: $10.3892 /$ ijo.2012.1686

\begin{abstract}
The aim of the present study was to assess whether (-)-epigallocatechin 3-gallate (EGCG) via epigenetic modifications, regulates Raf kinase inhibitor protein (RKIP) expression and invasive metastatic activity in AsPC-1 pancreatic adenocarcinoma cells. Basal levels of RKIP were examined in various human pancreatic cancer cell lines and MTT assay was used to assess cell viability. AsPC-1 cells were treated with EGCG with/ without trichostatin A (TSA), as the positive control, for $24 \mathrm{~h}$. The levels of RKIP and histone H3 induction were analyzed by immunoblot analysis. In order to determine the role of RKIP induction in NF- $\mathrm{NB}$ translocation and invasive metastatic activity in AsPC-1 cells, we examined NF- $\kappa$ B translocation, invasive metastatic parameters by RT-PCR, metastasis-related proteins by western blot analysis and matrix metalloproteinase (MMP)-2 and -9 activity by gelatin zymography. To validate RKIP induction through the extracellular signal regulated kinase (ERK) pathway, the cells were treated with U0126, an ERK inhibitor. Our results showed that EGCG induced RKIP upregulation via the inhibition of histone deacetylase (HDAC) activity which increased histone $\mathrm{H} 3$ expression and inhibited Snail expression, NF- $\kappa \mathrm{B}$ nuclear translocation, MMP-2 and -9 activity and Matrigel invasion in AsPC-1 cells. The expression of E-cadherin in the cells was upregulated. The phosphorylation of ERK was decreased by RKIP induction following EGCG treatment. Furthermore, our results confirmed that U0126 treatment repressed ERK phosphorylation and induced RKIP expression. Taken together, our results strongly suggest
\end{abstract}

Correspondence to: Dr Sung Ok Kim, Department of Herbal Pharmacology of Oriental Medicine, College of Oriental Medicine and R\&D Team for the New Drug of Oriental Medicine (BK21), Daegu Hanny University, 165 Sang-dong, Suseong-gu, Daegu 706-828, Republic of Korea

E-mail: sokim@dhu.ac.kr

Key words: (-)-epigallocatechin 3-gallate, Raf kinase inhibitor protein, pancreatic adenocarcinoma, AsPC-1 cells, histone deacetylation, invasion that EGCG regulates RKIP/ERK/NF- $\kappa \mathrm{B}$ and/or RKIP/NF- $\kappa \mathrm{B} /$ Snail and inhibits invasive metastasis in the AsPC-1 human pancreatic adenocarcinoma cell line.

\section{Introduction}

Cancer is a serious public health issue worldwide. Pancreatic cancer (PC) is the fourth to fifth most common type of cancer in Western countries and has the highest case-fatality rate of any of the major cancer types (1). In Korea, the prevalence of PC is generally increasing by $1.7 \%$ per year and in 2008 , the mortality rate from PC was ranked fifth (2). The only effective therapy is surgical excision, yet only 10 to $15 \%$ of patients have disease localized to the pancreas at the time of diagnosis (3). The majority of patients with PC succumb to the disease due to recurrence and metastatis. However, the etiology of PC is not yet fully understood. Previous studies have demonstrated that inflammation, which occurs as a response to most chronic illnesses, may play a significant role in this form of carcinogenesis (3-5). For example, pro-inflammatory cytokines induce the activation of NF- $\kappa \mathrm{B}$ via the phosphorylation of the extracellular signal regulated kinase (ERK) pathway, increase Snail expression and the secretion of invasion-promorting matrix metalloproteinases (MMPs) (5-8). Therefore, controlling inflammation is a significant factor in decreasing the risk of developing human PC.

Protein acetylation influences cellular processes including transcriptional regulation via the recruitment of enzymes, histone acetyltransferases (HATs) and histone deacetylases (HDACs) (9). Acetylation of specific lysine residues within the amino-terminal tails of nucleosomal histones is generally linked to chromatin disruption and the transcriptional activation of genes (10). HDAC inhibitors have been reported to induce cell growth arrest, apoptosis and differentiation in tumor cells $(10,11)$. Thus, dysregulation of the balance between protein acetylation and deacetylation is often associated with the initiation of tumorigenesis, cancer metastasis and other diseases.

The antioxidant and/or anti-inflammatory effects of dietary polyphenols (curcumin and resveratrol) have been shown to play a role in either controlling chromatin remodelling or $\mathrm{NF}-\kappa \mathrm{B}$ activation through the modulation of HDAC activity and subsequently, the expression of various genes $(11,12)$. 
(-)-Epigallocatechin-3-gallate (EGCG), an antioxidant found in green tea, has been reported to inhibit HAT and/or HDAC activity by a number of studies (13-18). EGCG decreases the hyperacetylation of $\mathrm{p} 65$ by directly inhibiting the activity of HAT enzymes. This hypoacetylation of p65 leads to the downregulation of NF- $\mathrm{KB}$ activity by diverse inflammatory signals (13). Although the regulation of NF- $\mathrm{KB}$ activity by histone deacetylation is a potential anti-metastatic mechanism in various types of cancer, the precise role of EGCG in human PC cells remains unclear. Thus, we hypothesized that EGCG inhibits invasive metastaic activity through the suppression of the NF- $\kappa \mathrm{B}$ signaling pathway by inducing RKIP expression and inhibiting HDAC activity in human PC cells.

RKIP, a 23-kDa protein, was identified as a physiological inhibitor of the Raf-MEK-ERK pathway (6), it is a member of the phosphatidylethanolamine-binding protein (PEBP) family (19) and is well known for its metastasis suppressor function in various types of cancer, including prostate, breast, colorectal, cervical cancer and malanoma. The loss or diminution of RKIP expression has been associated with the increasing number of aggressive cancers (20-24). Studies have suggested that NF- $\mathrm{KB}$ activation by RKIP diminution negatively interferes with NF- $\kappa$ B signaling (25-27). Several genes with tumor suppressive functions are thought to be silenced by aberrant histone modifications (28). Inhibitors of HDAC, such as trichostatin A (TSA), sodium butyrate (NaBT) and suberoylanilide hydroxamic acid (SAHA), have displayed anti-cancer activities by inducing the expression of downregulated genes related to metastasis, motility and invasiveness (28-31). First of all, we tested that RKIP expression in PC cell lines was induced by TSA through the modulation of HDAC activity. And then we examined whether EGCG can prevent PC metastasis by inhibiting HDAC activity and inducing RKIP expression, thus inhibiting cell signaling pathways involved in proliferation, survival and metastasis.

MMPs, a family of Zinc-dependent endopeptidases, are collectively capable of cleaving virtually all extracellular matrix (ECM) substrates, and play an important role in some physiological and pathological processes $(32,33)$. MMPs have also been implicated as possible mediators of invasion and metastasis in breast cancer, colon cancer and melanoma cell lines $(34,35)$. Since MMPs have many physiological functions in metastasis, the inhibition of the activity of MMPs holds great promise for the prevention or inhibition of metastasis. MMP-2 (gelatinases) is preferentially secreted from fibroblasts and various epithelial cells, while MMP-9 (gelatinases) is preferentially expressed by inflammatory cells (36), and both have been frequently associated with the invasive metastatic potential of tumor cells. However, the biochemical mechanisms underlying the EGCG-induced inhibition of metastasis and invasion are not clear in AsPC-1 PC cells.

Snail was identified as a transcription factor implicated in the epithelial-mesenchymal transition (EMT) during embryonic development (37). The increased expression of Snail in invasive cancer cells accompanied with the loss of E-cadherin expression has been reported in many types of human cancer, including melanoma, hepatocarcinoma and squamous cell carcinoma (38-40). E-cadherin is a cell-cell adhesion molecule that is specifically expressed on the membranes of epithelial cells, and its decreased expression has been reported to play a role in the invasion and metastasis of cancers $(41,42)$. The downregulation of E-cadherin expression has been explained by the DNA hypermethylation of its promoter region in breast and prostate cancer cells (43).

Therefore, in this study, we investigated the induction of RKIP expression by EGCG through the modification of histone deacetlyation. We also examined the effects of RKIP induction by EGCG on metastasis and invasive parameters, including MMP activity by gelatin zymography, Matrigel membrane invasion and metastasis-related proteins by western blot analysis using the AsPC-1 human adenocarcinoma metastatic cell line.

\section{Materials and methods}

Cell culture and cell viability. The human PC cell lines (Table I), MIA PaCa-2, AsPC-1, PANC-1 and BxPC-3, were obtained from the American Type Culture Collection (ATCC; (Rockville, MD) and cultured in DMBM and IMDM supplemented with $10 \%$ fetal bovine serum (FBS) and fetal calf serum (FCS) (Gibco BRL, Grand Island, NY) at $37^{\circ} \mathrm{C}$ in a humidified atmosphere containing $5 \% \mathrm{CO}_{2}$. For the cell viability assay, the cells were plated at $1 \times 10^{4}$ cells/well in $200 \mu \mathrm{l}$ medium containing $10 \mu \mathrm{M}$ EGCG with/without $1 \mu \mathrm{M}$ TSA (Sigma-Aldrich, St. Louis, MO) in a 96-well plate (Nunc ${ }^{\mathrm{TM}}$, Roskilde, Denmark). After incubation with concentrations of $0,5,10,15 \mu \mathrm{M}$ EGCG for $24 \mathrm{~h}$, cell viability was determined using 3-(4,5-dimethylthiazol-2-yl)-2,5-diphenyltetrazolium bromide (MTT) assay, which is based on the conversion of MTT to MTT-formazan by mitochondria. Cells were incubated with $1 \mathrm{mg} / \mathrm{ml}$ MTT (Chemicon, Temecula, CA) in PBS for $4 \mathrm{~h}$ at $37^{\circ} \mathrm{C}$ in $5 \% \mathrm{CO}_{2}$. Isopropanol and hydrochloric acid were then added at final concentrations of $50 \%$ and $20 \mathrm{mM}$, respectively. The optical density at $570 \mathrm{~nm}\left(\mathrm{OD}_{570}\right)$ was determined using an ELISA plate reader (MN 3663 Molecular Devices Co., Sunnyvale, CA) with a reference wavelength of $630 \mathrm{~nm}$.

MMP activity using gelatin zymography. Cell-free supernatant was collected and mixed with $2 \mathrm{X}$ sample buffer and then subjected to Novex Zymogram gels (Invitrogen, Camarillo, CA). After electrophoresis, the gels were washed twice at room temperature or $30 \mathrm{~min}$ in $2.5 \%$ Triton X-100, subsequently washed in buffer containing $50 \mathrm{mM}$ Tris- $\mathrm{HCl}, 150 \mathrm{mM} \mathrm{NaCl}$, $5 \mathrm{mM} \mathrm{CaCl}_{2}, 1 \mu \mathrm{M} \mathrm{ZnCl}_{2}, 0.02 \% \mathrm{NaN}_{3}$ at $\mathrm{pH} 7.5$ and incubated in this buffer at $37^{\circ} \mathrm{C}$ for $24 \mathrm{~h}$. Thereafter, the gels were stained with $0.25 \%$ (w/v) Coomassie brilliant blue G-250 (Bio-Rad Laboratoties, Hercules, CA) and then lightly destained in water solution containing methanol and acetic acid for $1 \mathrm{~h}$, respectively. The gelatinolytic activity was evidenced as clear bands (area of gelatin degradation) against the blue background of stained gelatin.

Matrigel invasion assay. In order to determine the effects of EGCG on AsPC-1 cell invasivness, the cells were exposed to $10 \mu \mathrm{M}$ of EGCG for $6 \mathrm{~h}$ and the pre-treated cells were plated onto the apical side of the Matrigel-coated filters (Sigma-Aldrich) in serum-free medium containing either EGCG or DMSO. Medium containing 20\% FBS was placed in the basolateral chamber to act as a chemoattractant. After $72 \mathrm{~h}$, cells on the apical side were wiped off using a Q-tip. The 
Table I. Comparisons of pancreatic cancer cell lines. ${ }^{a}$

\begin{tabular}{|c|c|c|c|}
\hline & Organism & $\begin{array}{l}\text { Growth } \\
\text { properties }\end{array}$ & Disease \\
\hline MIA PaCa-2 & $\begin{array}{l}\text { Homo sapiens } \\
\quad \text { (human) }\end{array}$ & $\begin{array}{l}\text { Adherent, single cells, } \\
\text { loosely attached clusters }\end{array}$ & Carcinoma \\
\hline BxPC-3 & $\begin{array}{l}\text { Homo sapiens } \\
\quad \text { (human) }\end{array}$ & Adherent & Adenocarcinoma \\
\hline PANC-1 & $\begin{array}{l}\text { Homo sapiens } \\
\text { (human) }\end{array}$ & Adherent & $\begin{array}{l}\text { Epithelioid } \\
\text { carcinoma }\end{array}$ \\
\hline AsPC-1 & $\begin{array}{l}\text { Homo sapiens } \\
\quad \text { (human) }\end{array}$ & Adherent & $\begin{array}{l}\text { Adenocarcinoma } \\
\text { (metastatic cells) }\end{array}$ \\
\hline
\end{tabular}

${ }^{\mathrm{a}}$ Www. atcc.org (American Type Culture Collection).

Table II. Oligonucleotides used in RT-PCR.

Gene Primer sequence

\section{GAPDH}

Sense 5'-CGG AGT CAA CGG ATT TGG TCG TAT-3'

Antisense 5'-AGC CTT CTC CAT GGT GGT GAA GAC-3'

RKIP

Sense $\quad$ 5'- CAC AAT GTG ATT TTA TGG T -3'

Antisense 5'- TCT TCA TTC AGG TTT CTA T -3'

E-cadherin

Sense 5'- GAA CAG CAC GTA CAC AGC CCT-3'

Antisense 5'- GCA GAA GTG TCC CTG TTC CAG-3'

Snail

Sense $\quad$ 5'- TAT GCT GCC TTC CCA GGC TTG-3'

Antisense 5'- ATG TGC ATC TTG AGG GCA CCC-3'

MMP-2

Sense 5'-CAG GCT CTT CTC CTT TCG CAA C-3'

Antisense 5'-AAG CCA CGG CTT GGT TTT CCT C-3'

MMP-9

Sense 5'-TGG GCT ACG TGA CCT ATG ACC AT-3

Antisense 5'-GCC CAG CCC ACC TCC ACT CCT C-3'

cells on the bottom of the filter were stained with hematoxylin and eosin $\mathrm{Y}$ and then counted (three fields of each triplicate filter) using an inverted microscope (Nikon, Tokyo, Japan).

RNA isolation and reverse transcription-polymerase chain reaction (RT-PCR). Total RNA was isolated using RNeasy (Qiagen, Valencia, CA). RNA (1 $\mu \mathrm{g})$ was reverse-transcribed in a $20 \mu 1$ reaction mixture using MMLV reverse transcriptase (Invitrogen). The cDNA was amplified in a $20 \mu 1$ reaction mixture. The PCR conditions were as follows: $0.4 \mu \mathrm{M}$ of each primer (Table II), $0.2 \mathrm{mM}$ deoxynucleoside triphosphate mixture (Perkin-Elmer, Norwalk, CT, USA), $50 \mathrm{mM} \mathrm{KCl}$, $10 \mathrm{mM}$ Tris- $\mathrm{HCl}(\mathrm{pH} 8.3), 1.5 \mathrm{mM} \mathrm{MgCl}{ }_{2}$, and $1.0 \mathrm{U}$ of Taq DNA polymerase (Perkin-Elmer). The reaction mixtures were incubated in a thermal controller (Model PTC-100; MJ Research, Ramsey, MN) for 35 cycles (denaturation at $94^{\circ} \mathrm{C}$ for $45 \mathrm{sec}$, annealing at $55^{\circ} \mathrm{C}$ for $45 \mathrm{sec}$, extension at $72^{\circ} \mathrm{C}$ for $90 \mathrm{sec}$ ). The PCR products were resolved on $1 \%$ agarose gels containing ethidum bromide (EtBr). The intensities of the bands were measured using an image documentation system (ImageMaster VDS; Pharmacia, Uppsala, Sweden) with image analysis software (ImageMaste TotalLab; Pharmacia). The DNA size marker was run in parallel to validate the predicted sizes of the amplified bands (GeneRuler $1 \mathrm{~kb}$ DNA Ladder; MBI, Amherst, NY). GADPH, MMP-2 and -9, RKIP, Snail, E-cadherin and ERK primer sequences were designed using Beacon Designer software (Premier Biosoft, Palo Alto, CA) and synthesized by IDT (Skokie, IL).

Immunoblot analysis. Western immunoblots were prepared to analyze the protein levels. After pre-treatment with the ERK inhibitor, U0126, for $1 \mathrm{~h}$ and treatment with/without EGCG for $24 \mathrm{~h}$, the cells were harvested and then proteins were extracted with NP-40 protein lysis buffer compositions; $50 \mathrm{mM}$ Tris-HCl (pH 7.5), $150 \mathrm{mM} \mathrm{NaCl}, 5 \mathrm{mM}$ EDTA, $25 \mathrm{mM} \mathrm{NaF}$, $10 \mathrm{mM}$ sodium pyrophosphate, $25 \mathrm{mM} \beta$-glycerophosphate, $0.2 \mathrm{mM} \mathrm{Na} \mathrm{VO}_{4}, 10 \mu \mathrm{g} / \mathrm{ml}$ leupeptin, $10 \mu \mathrm{g} / \mathrm{ml}$ aprotinin, protease inhibitor and $1 \mathrm{mM}$ PMSF. Cytoplasmic and nuclear extracts were prepared using NE-PER nuclear and cytosolic extraction reagents (Pierce, Rockford, IL). Quantification of protein concentration was carried out using the Bradford method (Bio-Rad protein assay reagent) and total protein was resuspended in Laemmli sample buffer containing 5\% $\beta$-mercaptoethanol and heated at $65^{\circ} \mathrm{C}$ for $10 \mathrm{~min}$. Aliquots containing $\sim 20-50 \mu \mathrm{g}$ of total cell proteins were resolved on $8-12 \%$ sodium dodecyl sulfate-polyacrylamide gel electrophoresis (SDS-PAGE) and then transferred onto nitrocellulose membranes (Amersham, Arlington Heights, IL). Membranes were blocked in 5\% non-fat milk (w/v) in Tris-buffered saline (TBS) containing $0.05 \%$ Tween-20 (TBST) for $1 \mathrm{~h}$ at room temperature and the membranes were subjected to immunoblot analysis with the desired antibodies (Table III). After an overnight incubation at $4^{\circ} \mathrm{C}$, the membranes were washed in TBST and incubated with the appropriate peroxidaseconjugated secondary antibody (Santa Cruz Biotechnology, 
Table III. List of antibodies used in this study.

\begin{tabular}{|c|c|c|c|}
\hline Antibody & Dilution & Species origin & Company \\
\hline MMP-2 & $1: 500$ & Rabbit polyclonal & Santa Cruz Biotechnology \\
\hline MMP-9 & $1: 500$ & Rabbit polyclonal & Santa Cruz Biotechnology \\
\hline ERK & $1: 1000$ & Rabbit polyclonal & Cell signaling \\
\hline pERK & $1: 1000$ & Rabbit polyclonal & Cell signaling \\
\hline $\mathrm{NF}-\kappa \mathrm{B}$ & $1: 1000$ & Rabbit polyclonal & Santa Cruz Biotechnology \\
\hline $\mathrm{I} \kappa \mathrm{B}$ & $1: 1000$ & Rabbit polyclonal & Santa Cruz Biotechnology \\
\hline p65 & $1: 500$ & Mouse polyclonal & Santa Cruz Biotechnology \\
\hline p50 & $1: 500$ & Rabbit polyclonal & Santa Cruz Biotechnology \\
\hline Snail & $1: 500$ & Rabbit polyclonal & Abcam \\
\hline E-cadherin & $1: 500$ & Mouse monoclonal & Santa Cruz Biotechnology \\
\hline Lamin B & $1: 1000$ & Rabbit polyclonal & Santa Cruz Biotechnology \\
\hline Actin & $1: 1000$ & Mouse monoclonal & Sigma \\
\hline
\end{tabular}
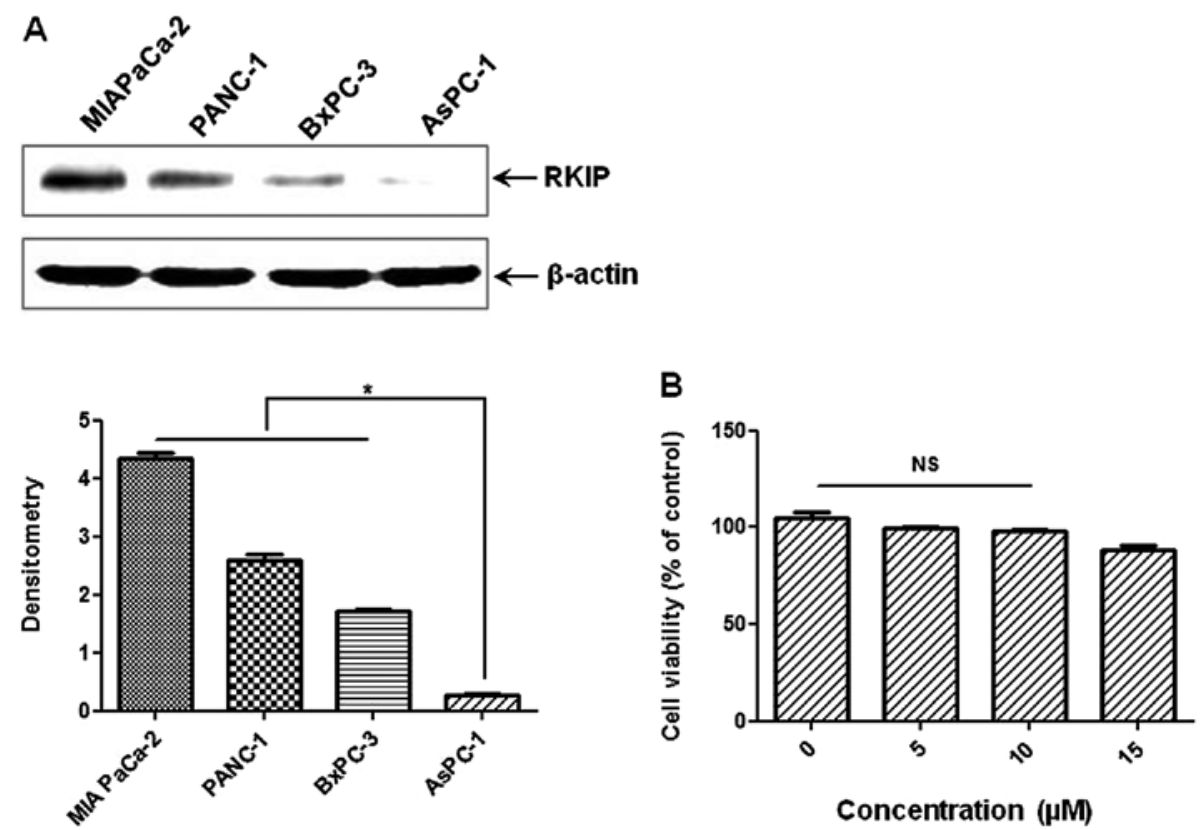

Figure 1. Baseline RKIP levels in pancreatic cancer cell lines and cell viability. (A) The cells for protein harvest were seeded at a density of $0.4 \times 10^{6}$ cells/well in a 6-well plate, respectively. The cells were lysed and then cellular proteins were separated by SDS-ployacrylamide gels and transferred onto nitrocellulose membranes. The membranes were probed with total RKIP, and $\beta$-actin antibodies, respectively. Proteins were visualized using an ECL detection system. $\beta$-actin was used as the internal control for protein loading. (B) Effects of EGCG on cell viability in AsPC-1 for $24 \mathrm{~h}$. Cells were seeded in 12 -well plates with $0.1 \times 10^{6}$ cells/well. The cells were then treated with or without $1 \mu \mathrm{M}$ TSA and $0,5,10,15 \mu \mathrm{M}$ EGCG in $1 \%$ FBS-DMEM, respectively. The cell viability was measured by the metabolic-dye-based MTT assay. Results are expressed as the means \pm SE of three independent experiments. Significance was determined by Student's t-test using GraphPhad Prism 5. Densitometry was performed using L process V2.01 and Muti Gauge V2.02. "p $<0.05$ vs. untreated control cells; NS, not significant.

Santa Cruz, CA). The membranes were developed using chemiluminescence according to the enhanced chemiluminescence western blotting detection reagent (Pierce).

Statistical analysis. All data are presented as the means \pm SD. Statistical analysis (Student's t-test) was performed using GraphPad Prism 5 (GraphPad Software, Inc., La Jolla, CA). Densitometry was performed using L process V2.01 and Muti Gauge V2.02 (Fuji Film, Stenford, USA). A value of * $\mathrm{p}<0.05$ was considered to indicate a statistically significant difference.
All the results presented in the figures shown in this study were obtained from at least three independent experiments.

\section{Results}

RKIP expression levels differ in human PC cell lines. The levels of baseline RKIP were investigated inthe PC cell lines, MIA PaCa-2, PANC-1, AsPC-1 and BxPC-3. As shown in Fig. 1, the order of the basal levels of RKIP between the cell lines was: MIA PaCa-2 > PANC-1 > BxPC-3 > AsPC-1. To 

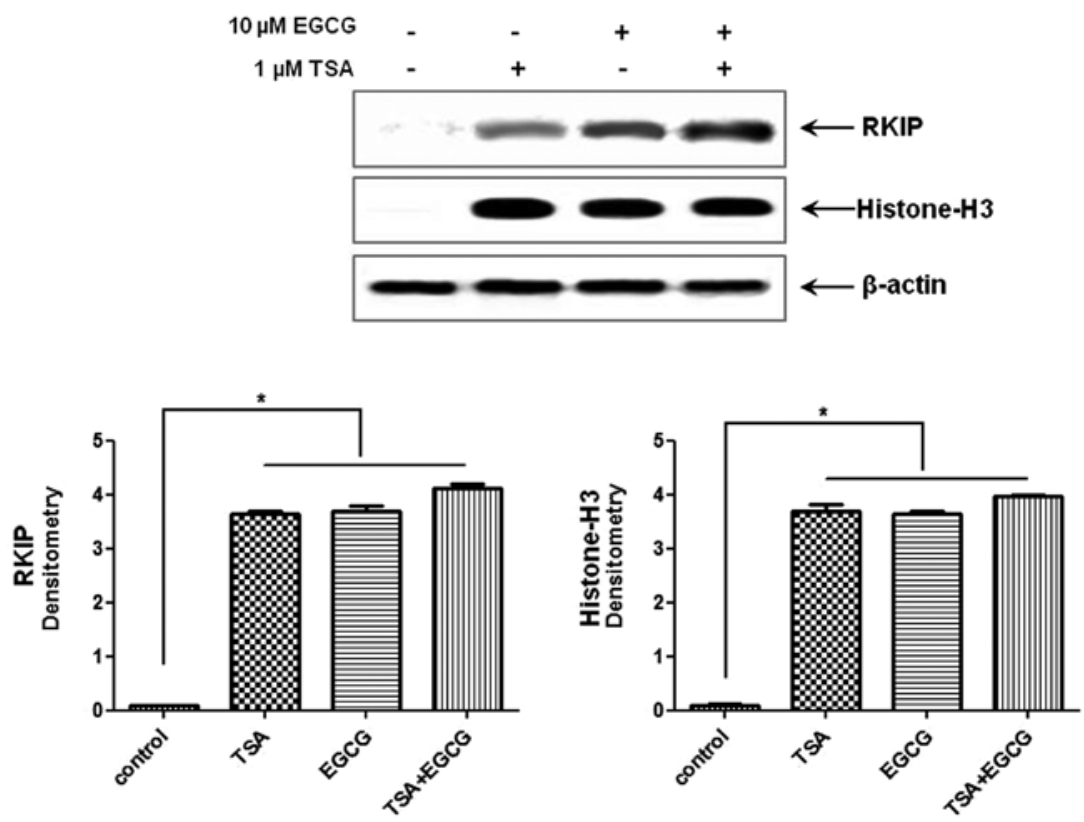

Figure 2. Total RKIP expressions levels in AsPC-1 cells following EGCG treatment with/without TSA. Optimal seeding of AsPC-1 cells for protein harvest was $0.4 \times 10^{6}$ cells/well incubated in $10 \%$ FBS-DMEM overnight. The cells were then treated with $10 \mu \mathrm{M}$ EGCG with or without $1 \mu \mathrm{M}$ TSA in $1 \%$ FBS-DMEM for $24 \mathrm{~h}$. The cells were lysed and then cellular proteins were analyzed by western blot analysis. The membranes were probed with total RKIP and histone H3 antibodies. Proteins were visualized using an ECL detection system. $\beta$-actin was used as the internal control for protein loading. Results are expressed as the means \pm SE of three independent experiments. Significance was determined by the Student's t-test using GraphPhad Prism 5 software. Densitometry analysis was performed using L process V2.01 and Muti Gauge V2.02. "p $<0.05$ vs. untreated control cells.

investigate whether RKIP expression was induced by EGCG treatment, we selected the AsPC-1 cell line, which had the lowest RKIP level of all the human PC cell lines. For further investigation, we examined the effect of EGCG on the viability of AsPC-1 cells by MTT assay. There was no toxicity up to $10 \mu \mathrm{M}$ EGCG (usual EGCG treatment, $15 \mu \mathrm{M}$ ). The dose of $10 \mu \mathrm{M}$ EGCG with/without TSA was used for the following experiment.

RKIP expression in AsPC-1 cells is upregulated by EGCG treatment. As shown in Fig. 2, treatment with $10 \mu \mathrm{M}$ EGCG, a major polyphenol in green tea, for $24 \mathrm{~h}$ induced RKIP expression in the AsPC-1 cells compared to the control cells. In order to confirm whether RKIP regulation in PC is due, in part, to histone modifications we performed the same experiments while causing RKIP induction with TSA, a known HDAC inhibitor. TSA induced RKIP expression and the effects were synergistic to those of EGCG. Histone H3 expression was significantly increased in the cells in which RKIP expression was induced compared to the control cells. Therefore, RKIP induction in AsPC-1 cells treated with EGCG is due, in part, to HDAC modifications.

EGCG inhibits translocation of $N F-\kappa B$ into the nucleus in AsPC-1 cells. The NF- $\mathrm{NB}$ signaling pathway is considerably involved in cancer cell metastasis and invasion. To investigate whether EGCG inhibits NF- $\kappa \mathrm{B}$ translocation in AsPC-1 cells, cytosolic and nuclear fractions were isolated in AsPC-1 cells. As shown in Fig. 3A and B, treatment with EGCG decreased the levels of p65 and p50 proteins in the nuclear fractions and elevated the levels of $\mathrm{NF}-\kappa \mathrm{B}$ and I $\mathrm{B}$ in the cytosolic frac- tions. These results indicte that the metastasis and invasion of cancer cells are inhibited by the regulation of $\mathrm{NF}-\kappa \mathrm{B}$ nuclear translocation. Therefore, we suggest that EGCG exerts antimetastatic and anti-invasion activities through the inhibition of NF- $\kappa \mathrm{B}$ nuclear translocation by the induction of RKIP and the inhibition of HDAC.

EGCG inhibits MMP activity and invasion in AsPC-1 cells. To investigate whether EGCG suppresses the activity of MMP-2 and -9 , gelatin zymography was performed on the AsPC-1 cells treated with EGCG. The activities of MMP-2 and -9 were decreased in the EGCG-treated cells compared to the control cells (Fig. 4A). EGCG had a greater inhibitory effect on MMP-9 activity than on MMP-2 activity. MMP activity is considered to be critically involved in cancer cell invasion. We then assessed the effects of EGCG on the invasiveness of AsPC-1 cells using Matrigel chamber invasion assay. The results of the Matrigel invasion assay (Fig. 4B) showed that the invasive capability of the AsPC-1 cells treated with EGCG was decreased compared to that of the control cells. These results indicate that EGCG inhibits the metastasis and invasion of human PC cells through HDAC modulation and the repression of MMP activity.

EGCG regulates expression levels of metastasis-related genes in AsPC-1 cells. To elucidate the mechanism by which EGCG inhibits metastasis and invasion, we examined the levels of metastasis-related genes, such as MMP-2 and -9, Snail and E-cadherin, using RT-PCR and western blot analysis. As shown in Fig. 5A and B, mRNA and protein levels of MMP-2 and -9, pERK and Snail were significantly downregulated 
A
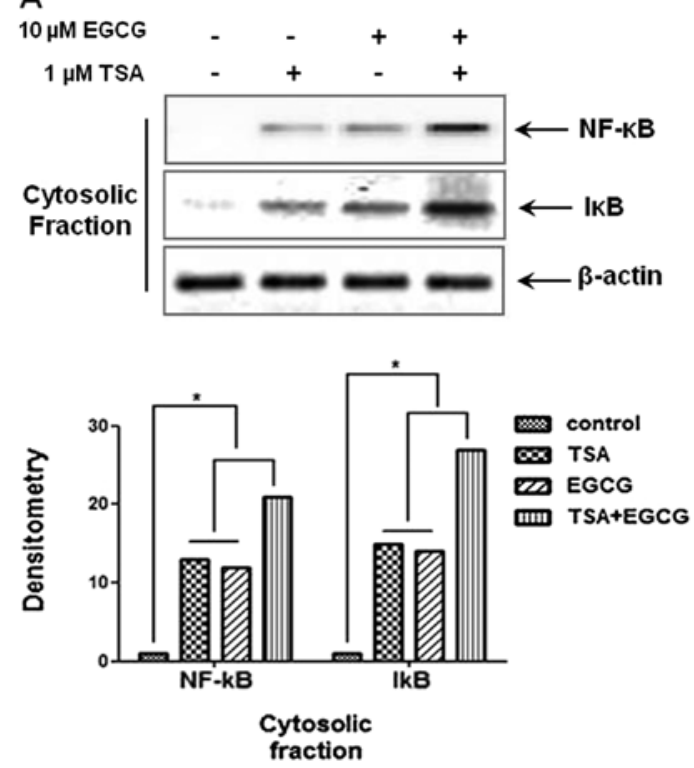

B
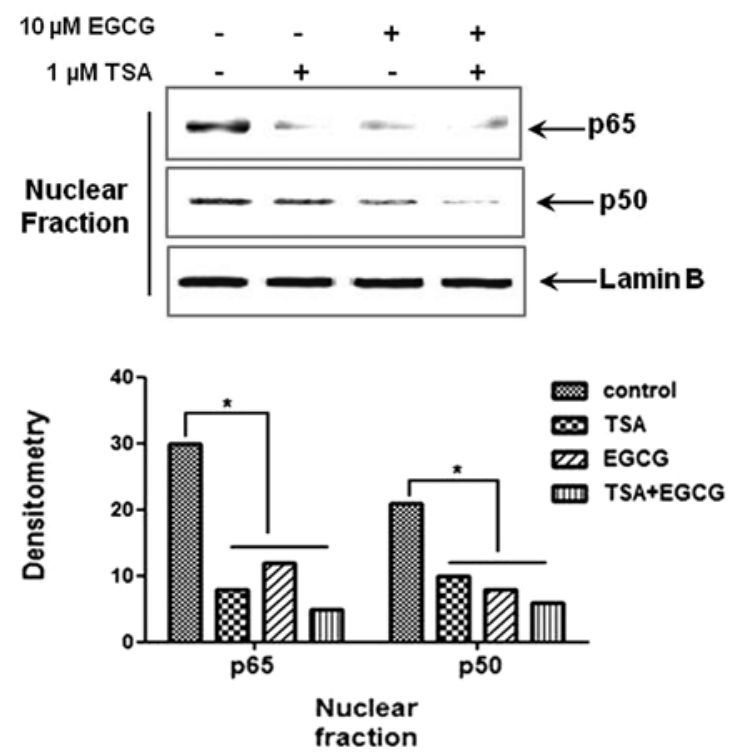

Figure 3. EGCG suppresses NF-אB activity. AsPC-1 cells were incubated with the indicated concentration of EGCG for $24 \mathrm{~h}$. (A and B) Cytosol and nuclear proteins were subjected to $10 \%$ SDS-PAGE and transferred onto nitrocellulose membranes. Protein levels were analyzed by western blot analysis using a specific antibody and then normalized to $\beta$-actin for cytosol protein fraction and lamin-B for nuclear protein fraction. Results are expressed as the means \pm SE of three independent experiments. Significance was determined by the Student's t-test using GraphPhad Prism 5 software. Densitometry analysis was performed using L process V2.01 and Muti Gauge V2.02. ${ }^{*}$ p $<0.05$ vs. untreated control cells.

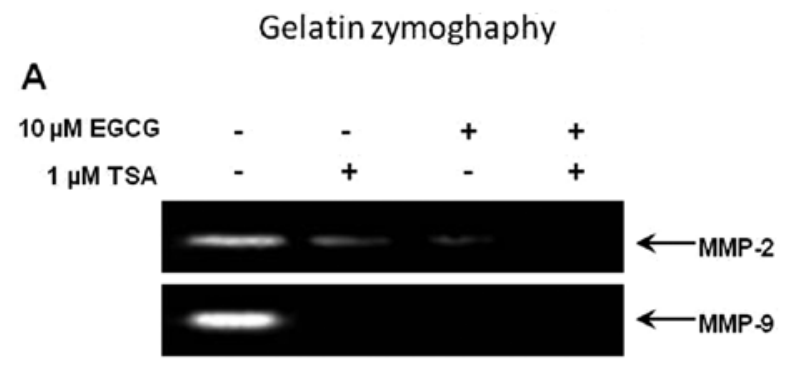

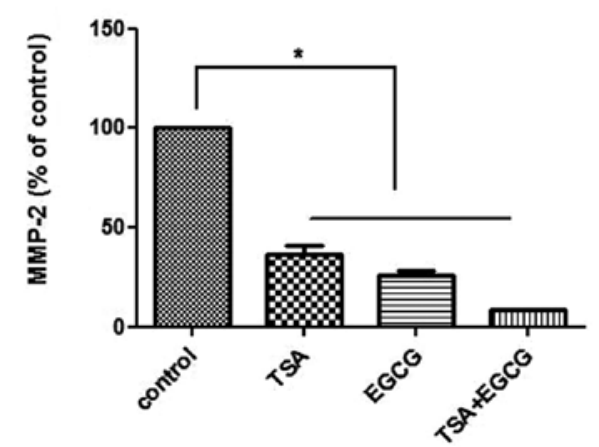

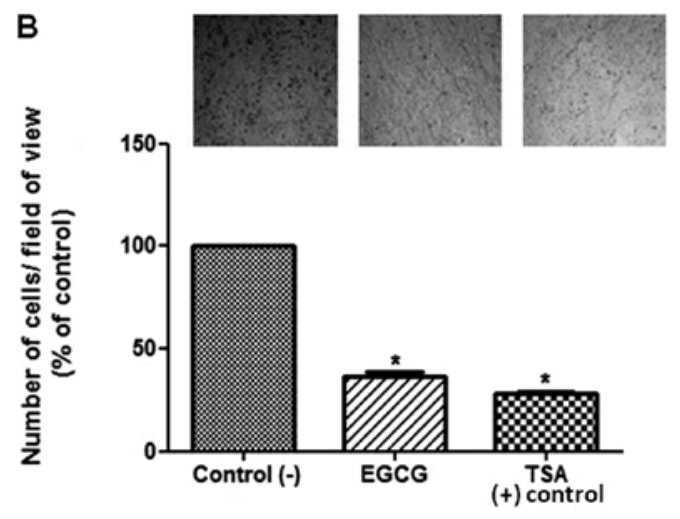

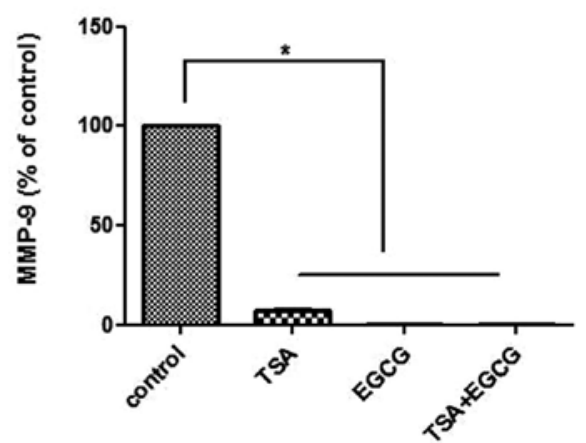

Figure 4. EGCG reduces the activity of MMP-2 and -9 and decreases cell invasion. (A) AsPc-1 cells were treated with the indicated concentration of EGCG for $24 \mathrm{~h}$. Conditional medium was collected after $24 \mathrm{~h}$, followed by gelatin zymography. (B) Cells pre-treated with EGCG for $24 \mathrm{~h}$ were plated onto the apical side of Matrigel-coated filters in serum-free medium containing either the vehicle or EGCG. Medium containing 20\% FBS was placed in the basolateral chamber to act as a chemoattractant. After $24 \mathrm{~h}$, cells on the apical side were wiped off using a Q-tip. Next, cells on the bottom of the filter were stained using hematoxylin and eosin, and then counted. Results are expressed as the means \pm SE of three independent experiments. Significance was determined by the Student's t-test using GraphPhad Prism 5 software. Densitometry analysis was performed using L process V2.01 and Muti Gauge V2.02. " $\mathrm{p}<0.05$ versus untreated control cells. 
A
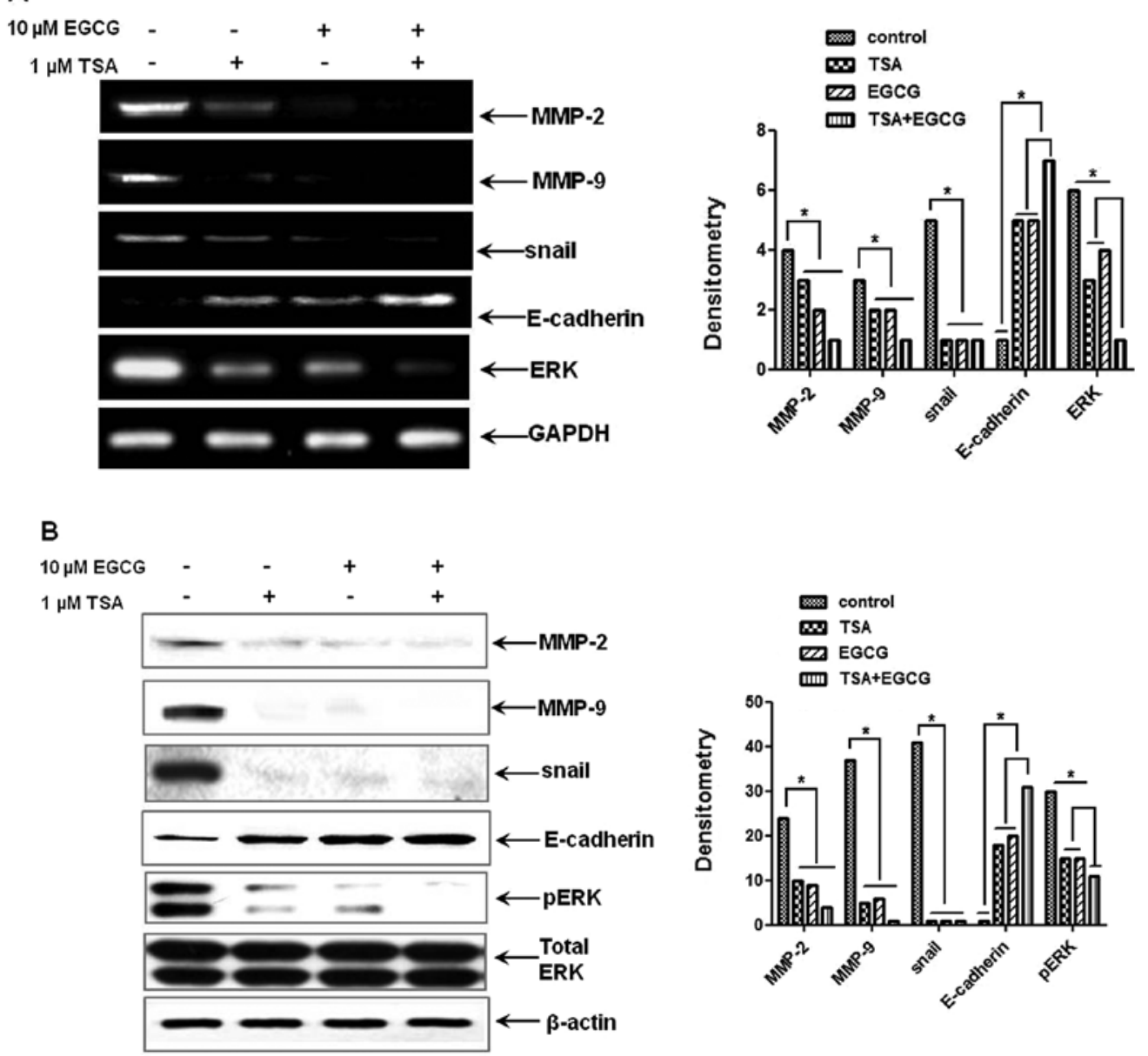

\section{C}
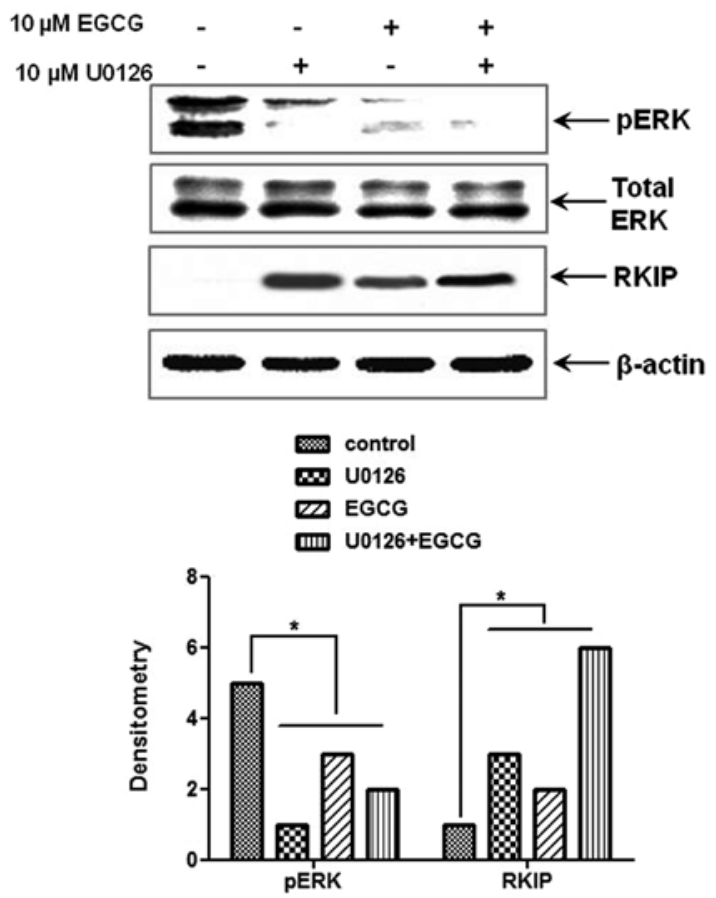

Figure 5. Effects of EGCG on the expression of invasive metastastic parameters in AsPC-1 cells. (A) Following treatment with EGCG for $24 \mathrm{~h}$, total RNA was isolated and RT-PCR analyses were performed as described in Materials and methods. GAPDH was used as the house-keeping control gene. (B) Equal amounts of cell lysate were resolved by SDS-PAGE and transferred onto nitrocellulose membranes. Western blot analysis was then performed using the indicated antibodies and the ECL detection system. $\beta$-actin was used as the internal control for protein loading. (C) Effects of ERK inhibitor on the levels of RKIP expression in AsPC-1 cells. Cells were treated with the indicated concentrations of EGCG for $24 \mathrm{~h}$. The cells were treated with U0126 $(10 \mu \mathrm{M})$, an ERK inhibitor, $1 \mathrm{~h}$ prior to EGCG treatment. After incubation with EGCG and/or U0126 equal amounts of cell lysate were resolved by SDS-PAGE, transferred onto nitrocellulose membranes, and probed with the indicated antibodies. $\beta$-actin was used as the internal control for loading control. Results are expressed as the means \pm SE of three independent experiments. Significance was determined by the Student's t-test using GraphPhad Prism 5 software. Densitometry analysis was performed using L process V2.01 and Muti Gauge V2.02. ${ }^{*}$ p $<0.05$ vs. untreated control cells.

in the EGCG-treated AsPC-1 cells compared to those of the control cells. The level of E-cadherin, a Snail nuclear translocation inhibitor, was markedly increased by EGCG treatment.
As RKIP regulates the activation of NF- $\kappa \mathrm{B}$ via the MEK/ERK signaling pathway (44), we investigated whether treatment with EGCG inhibits the phosphorylation of ERK. As shown 
in Fig. 5C, the treatment of cells with EGCG suppressed the phosphorylation of ERK compared to the control cells and increased RKIP expression. These results prove that the induction of RKIP expression by EGCG inhibits the phosphorylation of ERK and NF- $\kappa \mathrm{B}$ activation and decreases Snail expression. Therefore, EGCG as a HDAC inhibitor, can prevent the invasive metastasis of human PC cells.

\section{Discussion}

$\mathrm{PC}$ is the most severe gastrointestinal malignancy due to its propensity for local invasion and early metastasis $(45,46)$. Modulation of histone deacetylation by a HDAC inhibitor has been associated with transcriptional repression, an important epigenetic event that plays a critical role in inflammation (47). Inhibitors of HDACs, such as TSA, have been shown to display anti-cancer activities by inducing the expression of otherwise silenced genes (28). In this study, our objective was to treat PC cells with EGCG and investigate its effects on RKIP levels within the cells and determine whether an association exists between RKIP levels and cell metastasis.

RKIP was initially identified as a PEBP in the bovine brain. It was later identified as a protein that inhibits the Raf kinase activation of MEK (47). RKIP has a multi-functional role, exerting an inhibitory effect on pathways involved in cell proliferation, survival and metastasis (47-49). Beach et al, as well as others have reported that the expression levels of RKIP proteins progressively decrease in breast and prostate cancer cell lines of increasing metastatic potential $(48,50)$. A decrease in RKIP expression can promote invasion in other types of cancer and the induction of RKIP expression with HDAC inhibitors exerts anti-cancer effects in the majority of cancer cells by suppressing the activity of metastasis-related genes $(26,49)$. In this study, treatment with EGCG caused the induction of RKIP expression in PC cells. Our results confirmed that the regulation of RKIP expression in PC cells was due, in part, to histone modifications following treatment with HDAC inhibitors, such as TSA. EGCG suppressed the invasive and metastatic abilities of the PC cells. These effects correlated with RKIP expression. In accordance with our results, Fujimori et al also reported that the loss of RKIP expression was associated with tumor progression and poor survival. Negative RKIP expression combined with positive p-ERK expression is an independent predictor of poor outcomes in patients with gastric cancer (51). Evidence has emerged that RKIP can function as a suppressor of cancer metastasis.

EGCG, a green tea-derived polyphenol, has been reported to exert an inhibitory effect on $\mathrm{NF}-\kappa \mathrm{B}$ activity in various human malignancies (13-16). However, the mechanisms behind the EGCG regulation of NF- $\mathrm{NB}$-dependent activation in $\mathrm{PC}$ cells remain unclear (whether EGCG acts by regulating the stability or inhibiting the activity of invasive metastatic proteins). In this study, to determine whether RKIP is repressed by HDAC in PC cells, we investigated the effects of EGCG on RKIP expression levels in AsPC-1 cells. EGCG treatment led to the induction of RKIP expression within $24 \mathrm{~h}$ and inhibited $\mathrm{NF}-\kappa \mathrm{B}$ nuclear translocation by suppressing ERK phosphorylation in the cells. The same experiments performed using TSA in the cells showed similar results at $1 \mu \mathrm{M}$ TSA concentration. These results confirm that EGCG acts as a HDAC inhibitor to suppress pro-inflammatory events, such as NF- $\mathrm{NB}$ activation. Tang et al and Yeung et al reported that RKIP negatively regulates the Raf/MEK/ERK and NF- $\kappa \mathrm{B}$ pathways $(5,6)$. Li et al reported that EGCG, in combination with the HDAC inhibitor, TSA, led to the synergistic epigenetic reactivation of estrogen receptor- $\alpha(\mathrm{ER} \alpha)$ in $\mathrm{ER} \alpha$-negative breast cancer cells (16).

MMPs are considered important proteolytic enzymes during organ development and tissue regeneration. However, they also play important roles in cancer invasion and metastasis. In particular, MMP-2 and -9 play important roles in tumor invasion and angiogenesis; therefore, tumor metastasis may be inhibited by blocking MMP synthesis and activity $(32,33)$. Hazgui et al (52) reported that the anti-metastatic activity of a polyphenolic constituent of green tea, EGCG, was associated with a reduction in MMP-2 activity. In a study by Shankar et al (53), it was reported that EGCG-treated mice with PC had a significantly reduced ERK activity, invasion, metastasis and angiogenesis. Takada et al (54) demonstrated that indole-3-carbinol, a phytochemical agent, inhibited the cell proliferation and invasion of leukemic cells by inhibiting MMP-9 activity. Additionally, Jin et al (55) reported that Snail plays a critical role in tumor growth and metastasis of ovarian carcinoma through the regulation of MMP activity. These results may explain why the expression of MMP-2 and -9 is elevated in parametrial invasion. Our results indicated a marked inhibition of MMP-2 and -9 mRNA, protein levels and activities following treatment with EGCG with/without TSA. Snail and E-cadherin expression has also been related to cancer metastasis and MMP activity. In accordance with our results, Miyoshi et al suggested that Snail, a zinc-finger transcription factor, represses E-cadherin expression and induces MMP expression, which causes vascular invasion and intrahepatic metastasis in primary hepatocellular carcinoma tumors (56). Batlle et al reported that Snail regulates other genes required for the scattering process, in conjunction with E-cadherin downregulation (38).

Collectively, these data demonstrate that the green teaderived polyphenol, EGCG, regulates RKIP expression by modulating histone deacetylation. The results from the present study demonstrate that EGCG treatment leads to the inactivation of NF- $\mathrm{KB}$ and downstream target genes, such as Snail, as well as to the inactivation of MMPs, resulting in the inhibition of the invasive metastatic ability of PC cells. Therefore, we suggest that EGCG can potentially be a used as a therapeutic agent for PC. Further studies are required in order to gain a deeper understanding of the efficacy of EGCG in PC prevention. Future studies should focus on elucidating the molecular mechanisms involved by using in vivo methods with proper animal models of PC.

\section{References}

1. Jemal A, Siegel R, Xu J and Ward E: Cancer statistics 2010. CA Cancer J Clin 60: 277-300, 2010.

2. Korea Ministry of Health and Welfare: Annual report of cancer statistics in Korea in 2008. http://mw.go.kr, 2011.

3. Warshaw AL, Gu ZY, Wittenberg J and Waltman AC: Preoperative staging and assessment of resectability of pancreatic cancer. Arch Surg 125: 230-233, 1990.

4. Whitcomb DC: Inflammation and Cancer V. Chronic pancreatitis and pancreatic cancer. Am J Physiol Gastrointest Liver Physiol 287: G315-G319, 2004. 
5. Tang H, Park S, Sun SC, Trumbly R, Ren G, Tsung E and Yeung KC: RKIP inhibits NF-kappaB in cancer cells by regulating upstream signaling components of the IkappaB kinase complex. FEBS Lett 4: 662-668, 2009.

6. Yeung K, Janosch P, McFerran B, Rose DW, Mischak H Sedivy JM and Kolch W: Mechanism of suppression of the Raf/ MEK/extracellular signal-regulated kinase pathway by the raf kinase inhibitor protein. Mol Cell Biol 20: 3079-3085, 2000.

7. Barbera MJ, Puig I, Dominguez D, Julien-Grille S, GuaitaEsteruelas S, Peiró S, Baulida J, Francí C, Dedhar S, Larue L and García de Herreros A: Regulation of Snail transcription during epithelial to mesenchymal transition of tumor cells. Oncogene 23: 7345-7354, 2004.

8. Munshi HG and Stack MS: Reciprocal interactions between adhesion receptor signaling and MMP regulation. Cancer Metastasis Rev 25: 45-56, 2006.

9. Gregory PD, Wagner K and Horz W: Histone acetylation and chromatin remodeling. Exp Cell Res 265: 195-202, 2001.

10. Struhl K: Histone acetylation and transcriptional regulatory mechanisms. Genes Dev 12: 599-606, 1998.

11. Gray SG and Teh BT: Histone acetylation/deacetylation and cancer: an 'open' and 'shut' case? Curr Mol Med 1: 401-429, 2001.

12. Hayden MS and Ghosh S: Signaling to NF- $\kappa$ B. Genes Dev 18 : 2195-2224, 2004.

13. Choi KC, Jung MG, Lee YH, Yoon JC, Kwon SH, Kang HB Kim MJ, Cha JH, Kim YJ, Jun WJ, Lee JM and Yoon HG: Epigallocatechin-3-gallate, a histone acetyltransferase inhibitor, inhibits EBV-induced B lymphocyte transformation via suppression of RelA acetylation. Cancer Res 69: 583-592, 2009.

14. Thakur VS, Gupta K and Gupta S: Green tea polyphenols increase p53 transcriptional activity and acetylation by suppressing class I histone deacetylases. Int J Oncol 41: 353-361, 2012.

15. Choudhury SR, Balasubramanian S, Chew YC, Han B, Marquez VE and Eckert RL: (-)-Epigallocatechin-3-gallate and DZNep reduce polycomb protein level via a proteasomedependent mechanism in skin cancer cells. Carcinogenesis. 32 $1525-1532,2011$

16. Li Y, Yuan YY, Meeran SM and Tollefsbol TO: Synergistic epigenetic reactivation of estrogen receptor- $\alpha(E R \alpha)$ by combined green tea polyphenol and histone deacetylase inhibitor in ER $\alpha$-negative breast cancer cells. Mol Cancer 9: 274-286, 2010.

17. Yun JM, Jialal I and Devaraj S: Effects of epigallocatechin gallate on regulatory $\mathrm{T}$ cell number and function in obese $\mathrm{v}$. lean volunteers. Br J Nutr 103: 1771-1777, 2010.

18. Fang M, Chen D and Yang CS: Dietary polyphenols may affect DNA methylation. J Nutr 137: 223S-228S, 2007

19. Yeung K, Seitz T, Li S, Janosch P, McFerran B, Kaiser C, Fee F, Katsanakis KD, Rose DW, Mischak H, Sedivy JM and Kolch W: Suppression of Raf-1 kinase activity and MAP kinase signalling by RKIP. Nature 401: 173-177, 1999 .

20. Ren G, Baritaki S, Marathe H, Feng J, Park S, Beach S, Bazeley PS, Beshir AB, Fenteany G, Mehra R, Daignault S, Al-Mulla F, Keller E, Bonavida B, de la Serna I and Yeung KC: Polycomb protein EZH2 regulates tumor invasion via the transcriptional repression of the metastasis suppressor RKIP in breast and prostate cancer. Cancer Res 72: 3091-3104, 2012

21. Minn AJ, Bevilacqua E, Yun J and Rosner MR: Identification of novel metastasis suppressor signaling pathways for breast cancer. Cell Cycle 11: 2452-2457, 2012.

22. Karamitopoulou E, Zlobec I, Panayiotides I, Patsouris ES Peros G, Rallis G, Lapas C, Karakitsos P, Terracciano LM and Lugli A: Systematic analysis of proteins from different signaling pathways in the tumor center and the invasive front of colorectal cancer. Hum Pathol 42: 1888-1896, 2011.

23. Hu CJ, Zhou L, Zhang J, Huang C and Zhang GM: Immunohistochemical detection of Raf kinase inhibitor protein in normal cervical tissue and cervical cancer tissue. J Int Med Res 39: 229-237, 2011.

24. Zebisch A, Wölfler A, Fried I, Wolf O, Lind K, Bodner C, Haller M, Drasche A, Pirkebner D, Matallanas D, Rath O, Blyth K, Delwel R, Taskesen E, Quehenberger F, Kolch W, Troppmair J and Sill H: Frequent loss of RAF kinase inhibitor protein expression in acute myeloid leukemia. Leukemia 26 1842-1849, 2012.

25. Wu K and Bonavida B: The activated NF-kappaB-Snail-RKIP circuitry in cancer regulates both the metastatic cascade and resistance to apoptosis by cytotoxic drugs. Crit Rev Immunol 29: $241-254,2009$
26. Yeung KC, Rose DW, Dhillon AS, Yaros D, Gustafsson M, Chatterjee D, McFerran B, Wyche J, Kolch W and Sedivy JM: Raf kinase inhibitor protein interacts with NF-kappaB-inducing kinase and TAK1 and inhibits NF-kappaB activation. Mol Cell Biol 21: 7207-7217, 2001.

27. Karin M and Ben-Neriah Y: Phosphorylation meets ubiquitination: the control of NF-[kappa]B activity. Annu Rev Immunol 18: 621-663, 2000.

28. Emonds E, Fitzner B and Jaster R: Molecular determinants of the antitumor effects of trichostatin A in pancreatic cancer cells. World J Gastroenterol 16: 1970-1978, 2010.

29. Farrow B, Rychahou P, O'Connor KL and Evers BM: Butyrate inhibits pancreatic cancer invasion. J Gastrointest Surg 7: 864-870, 2003

30. Hardtner C, Multhoff G, Falk W and Radons J: (-)-Epigallocatechin-3-gallate, a green tea-derived catechin, synergizes with celecoxib to inhibit IL-1-induced tumorigenic mediators by human pancreatic adenocarcinoma cells Colo357. Eur J Pharmacol 684: 36-43, 2012.

31. Choi KC, Lee YH, Jung MG, Kwon SH, Kim MJ, Jun WJ, Lee J, Lee JM and Yoon HG: Gallic acid suppresses lipopolysaccharide-induced nuclear factor-kappaB signaling by preventing RelA acetylation in A549 lung cancer cells. Mol Cancer Res 7: 2011-2021, 2009

32. Zucker S, Cao J and Chen WT: Critical appraisal of the use of matrix metalloproteinase inhibitors in cancer treatment. Oncogene 19: 6642-6650, 2000.

33. Mook OR, Frederiks WM and Van Noorden CJ: The role of gelatinases in colorectal cancer progression and metastasis. Biochim Biophys Acta 1705: 69-89, 2004.

34. Duffy MJ, Maguire TM, Hill A, McDermott E and O'Higgins N: Metalloproteinases: role in breast carcinogenesis, invasion and metastasis. Breast Cancer Res 2: 252-257, 2000.

35. Vihinen P, Ala-aho R and Kähäri VM: Matrix metalloproteinases as therapeutic targets in cancer. Curr Cancer Drug Targets 5: 203-220, 2005 .

36. Gibbs DF, Warner RL, Weiss SJ, Johnson KJ and Varani J: Characterization of matrix metalloproteinases produced by rat alveolar macrophages. Am J Respir Cell Mol Biol 20: 1136-1144, 1999.

37. Yokoyama K, Kamata N, Hayashi E, Hoteiya T, Ueda N, Fujimoto R and Nagayama M: Reverse correlation of E-cadherin and snail expression in oral squamous cell carcinoma cells in vitro. Oral Oncol 37: 65-71, 2001

38. Batlle E, Sancho E, Francí C, Domínguez D, Monfar M, Baulida J and García De Herreros A: The transcription factor Snail is a repressor of E-cadherin gene expression in epithelial tumor cells. Nat Cell Biol 2: 84-89, 2000.

39. Jiao W, Miyazaki K and Kitajima Y: Inverse correlation of E-cadherin and Snail expression in hepatocellular cell lines in vitro and in vivo. Br J Cancer 86: 98-101, 2002.

40. Poser I, Domínguez D, de Herreros AG, Varnai A, Buettner R and Bosserhoff AK: Loss of E-cadherin expression in melanoma cells involves up-regulation of the transcriptional repression Snail. J Biol Chem 276: 24661-24666, 2001.

41. Luo J, Lubaroff DM and Hendrix MJ: Suppression of prostate cancer invasive potential and matrix metalloproteinase activity by E-cadherin transfection. Cancer Res 59: 3552-3556, 1999.

42. Oka H, Shiozaki H, Kobayashi K, Inoue M, Tahara H, Kobayashi T, Takatsuka Y, Matsuyoshi N, Hirano S, Takeichi M and Mori T: Expression of E-cadherin cell adhesion molecules in human breast cancer tissues and its relationship to metastasis. Cancer Res 53: 1696-1701, 1993.

43. Graff JR, Herman JG, Lapidus RG, Chopra H, Xu R, Jarrard DF, Isaacs WB, Pitha PM, Davidson NE and Baylin SB: E-cadherin expression is silenced by DNA hypermethylation in human breast and prostate carcinomas. Cancer Res 55: 5195-5199, 1995.

44. Odabaei G, Chatterjee D, Jazirehi AR, Goodglick L, Yeung K and Bonavida B: Raf-1 kinase inhibitor protein: structure, function, regulation of cell signaling, and pivotal role in apoptosis. Adv Cancer Res 91: 169-200, 2004.

45. Eckel F, Schneider G and Schmid RM: Pancreatic cancer: a review of recent advances. Expert Opin Investig Drugs 15: 1395-1410, 2006.

46. Schneider G, Siveke JT, Eckel F and Schmid RM: Pancreatic cancer: basic and clinical aspects. Gastroenterology 128: 1606-1625, 2005.

47. Escara-Wilke J, Yeung K and Keller ET: Raf kinase inhibitor protein (RKIP) in cancer. Cancer Metastasis Rev: Jun 9, 2012 (Epub ahead of print). 
48. Klysik J, Theroux SJ, Sedivy JM, Moffit JS and Boekelheide K: Signaling crossroads: the function of Raf kinase inhibitory protein in cancer, the central nervous system and reproduction. Cell Signal 20: 1-9, 2008.

49. Zeng L, Imamoto A and Rosner MR: Raf kinase inhibitory protein (RKIP): a physiological regulator and future therapeutic target. Expert Opin Ther Targets 12: 1275-1287, 2008.

50. Beach S, Tang H, Park S, Dhillon AS, Keller ET, Kolch W and Yeung KC: Snail is a repressor of RKIP transcription in metastatic prostate cancer cells. Oncogene 27: 2243-2248, 2008.

51. Fujimori Y, Inokuchi M, Takagi Y, Kato K, Kojima K and Sugihara K: Prognostic value of RKIP and p-ERK in gastric cancer. J Exp Clin Cancer Res 31: 30-38, 2012.

52. Hazgui S, Bonnomet A, Nawrocki-Raby B, Milliot $M$, Terryn C, Cutrona J, Polette M, Birembaut P and Zahm JM Epigallocatechin-3-gallate (EGCG) inhibits the migratory behavior of tumor bronchial epithelial cells. Respir Res 9: $33-46,2008$
53. Shankar S, Ganapathy S, Hingorani SR and Srivastava RK: EGCG inhibits growth, invasion, angiogenesis and metastasis of pancreatic cancer. Front Biosci 13: 440-452, 2008.

54. Takada Y, Andreeff M and Aggarwal BB: Indole-3-carbinol suppresses $\mathrm{NF}-\kappa \mathrm{B}$ and $\mathrm{I} \kappa \mathrm{B} \alpha$ kinase activation, causing inhibition of expression of NF- $\mathrm{kB}$-regulated antiapoptotic and metastatic gene products and enhancement of apoptosis in myeloid and leukemia cells. Blood 106: 641-649, 2005.

55. Jin H, Yu Y, Zhang T, Zhou X, Zhou J, Jia L, Wu Y, Zhou BP and Feng Y: Snail is critical for tumor growth and metastasis of ovarian carcinoma. Int J Cancer 126: 2102-2111, 2010.

56. Miyoshi A, Kitajima Y, Kido S, Shimonishi T, Matsuyama S, Kitahara K and Miyazaki K: Snail accelerates cancer invasion by upregulating MMP expression and is associated with poor prognosis of hepatocellular carcinoma. Br J Cancer 92: 252-258, 2005. 